\title{
Peritoneal Mesothelioma Associated with Polyclonal Hyperimmunoglobulinemia
}

\author{
SeiJu Onodera, Ryutaro Inaba, Katsumisa Nimkawa, \\ Kosuke Oikawa and Kaoru Yoshinaga \\ Department of Internal Medicine, Tohoku University School \\ of Medicine, Sendai
}

\begin{abstract}
Onodera, S., Inaba, R., Nirkawa, K., OtKawa, K. and Yoshinaga, K. Peritoneal Mesothelioma Associated with Polyclonal Hyperimmunoglobulinemia. Tohoku J. exp. Med., 1974, 114 (3), 195-203_ This patient had marked poly. clonal hyperimmunoglobulinemia associated with mesothelioma in the right sub. phrenic space. Histopathologically the lymph nodes around the mesothelioma showed marked plasma cell proliferation intermingled with infiltration of mesothelioma cells. The plasma cell proliferation was observed even in distant lymph nodes not infiltrated by the tumor cells. The review of the literature disclosed rather frequent occurrences of hyperimmunoglobulinemia in mesothelioma and significance of this association should be stressed. peritoneal mesothelioma; polyclonal hyperimmunoglobulinemia
\end{abstract}

It is well known that polyclonal hyperimmunoglobulinemia occurs in various diseases, such as chronic infections (Fahey 1965; Buchley and Dorsey 1970), collagen diseases (Barnett and MacDonald 1970), liver diseases (Fahey 1965) and some carcinomatous conditions (Fenoglio et al. 1973). The presence of polyclonal hyperimmunoglobulinemia probably reflects the proliferation of lymphoreticular system stimulated by some antigenic substance, but in majority of cases of polyclonal hyperimmunoglobulinemia it is extremely difficult to determine what the exact antigen responsible may be.

We have recently experienced a case of puzzling persistent polyclonal hyperimmunoglobulinemia. Extensive diagnostic approaches failed to disclose its underlying disease, but the autopsy disclosed the presence of mesothelioma in the subphrenic area. The histopathological findings suggest that this polyclonal hyperimmunoglobulinemia was closely related to metastasis of mesothelioma cells to the neighboring lymph nodes.

\section{Case Report}

This 20 year-old Japanese male clerk was admitted to Tohoku University Hospital on May 29, 1972, because of fever and upper abdominal pain. He had. been operated upon for acute appendicitis in 1969. In June, 1971 exploratory laparotomy was performed in a local hospital for the diffuse abdominal discomfort

Received for publication, August 12, 1974. 
TABLE 1. Laboratory data on admission

\begin{tabular}{|c|c|c|c|c|}
\hline \multirow[t]{4}{*}{ Urinalysis } & \multirow{4}{*}{$\begin{array}{l}\text { Protein }(+), \\
\text { sugar }(-), \\
\text { urobilinogen }(+) \text {, } \\
\text { Bence-Jones } \\
\text { protein }(-)\end{array}$} & \multicolumn{3}{|l|}{ Actual pH } \\
\hline & & Actual $\mathrm{P}_{\mathrm{CO}_{2}}$ & 33.2 & $\mathrm{mmHg}$ \\
\hline & & Base excess & -1.9 & $\mathrm{mEq} /$ liter \\
\hline & & Standard bicarbonate & 22.6 & $\begin{array}{l}\text { blood } \\
\mathrm{mEq} / \mathrm{liter}\end{array}$ \\
\hline $\mathrm{RBC}$ & $2.96 \times 10^{6} / \mathrm{mm}^{3}$ & & & plasma \\
\hline $\mathrm{Hb}$ & $7.1 \mathrm{~g} / 100 \mathrm{ml}$ & Icterus index & 10 & units \\
\hline Reticulocytes & 20 & Serum total bilirubin & 0.4 & $\mathrm{mg} / 100 \mathrm{ml}$ \\
\hline \multirow[t]{3}{*}{ WBC } & $10,100 / \mathrm{mm}^{3}$ & Serum indirect & 0.2 & $\mathrm{mg} / 100 \mathrm{ml}$ \\
\hline & $\begin{array}{l}\text { (Band } 21 \text {, Seg } 51 \text {, } \\
\text { Baso } 1 \text {, Mono } 17 \text {, }\end{array}$ & SGOT & 14 & units \\
\hline & Lymph $10 \%$ ) & SGPT & 12 & units \\
\hline Platelets & $211,000 / \mathrm{mm}^{3}$ & Serum alkaline & 13.4 & units \\
\hline Prothrombin time & $50 \%$ (one stage) & phosphatase & \multicolumn{2}{|c|}{ (King-Armstrong) } \\
\hline Bleeding time & $5^{\prime} 30^{\prime \prime}$ (Duke) & ESR $1 \mathrm{hr}$ & 152 & $\mathrm{~mm}$ \\
\hline Coagulation time & $8^{\prime} \quad$ (Lee-White) & RA-test & $(-)$ & \\
\hline Fibrinogen & $736.8 \mathrm{mg} / 100 \mathrm{ml}$ & CRP & $(+5)$ & \\
\hline Serum iron & $5 \mathrm{l} \quad \gamma / 100 \mathrm{ml}$ & ASLO titer & 833 & \\
\hline UIBC & $183 \gamma / 100 \mathrm{ml}$ & LE cell & $(-)$ & \\
\hline Serum sodium & $139 \mathrm{mEq} /$ liter & Antinuclear factors & $(-)$ & \\
\hline Serum potassium & $4.1 \mathrm{mEq} /$ liter & Coombs' test direct & $(+)$ & \\
\hline Serum chloride & $96 \mathrm{mEq} /$ liter & indirect & $(-)$ & \\
\hline Serum calcium & $8.0 \mathrm{mg} / 100 \mathrm{ml}$ & Paul-Bunnell test titer & 448 & \\
\hline Serum phosphorus & $4.3 \mathrm{mg} / 100 \mathrm{ml}$ & IgG & 3850 & $\mathrm{mg} / 100 \mathrm{ml}$ \\
\hline Total cholesterol & $80 \mathrm{mg} / 100 \mathrm{ml}$ & IgA & 420 & $\mathrm{mg} / 100 \mathrm{ml}$ \\
\hline Fasting blood glucose & $104 \mathrm{mg} / 100 \mathrm{ml}$ & $\operatorname{IgM}$ & 110 & $\mathrm{mg} / 100 \mathrm{ml}$ \\
\hline Serum uric acid & $2.6 \mathrm{mg} / 100 \mathrm{ml}$ & IgD & 5.6 & $\mathrm{mg} / 100 \mathrm{ml}$ \\
\hline Blood urea nitrogen & $10 \mathrm{mg} / 100 \mathrm{ml}$ & $\operatorname{IgE}$ & 160 & units/ml \\
\hline $\begin{array}{l}\text { Glomerular filtration } \\
\text { rate }\end{array}$ & $65.2 \mathrm{ml} / \mathrm{min}$ & & & \\
\hline
\end{tabular}

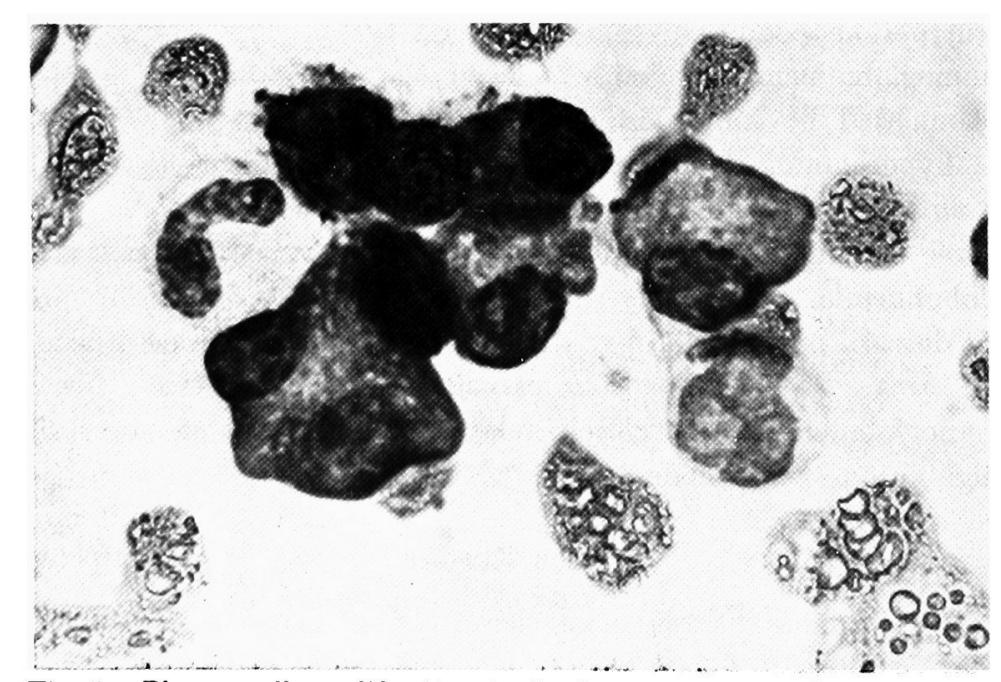

Fig. 1. Plasma cells proliferating in the bone marrow in October, 1972.

he began to complain of, but no remarkable finding was observed except for the presence of some ascitic fluid. In October, 1971 the abdominal pain with distention gradually increased and fever, fatigue, anorexia and anemia developed. Under the 


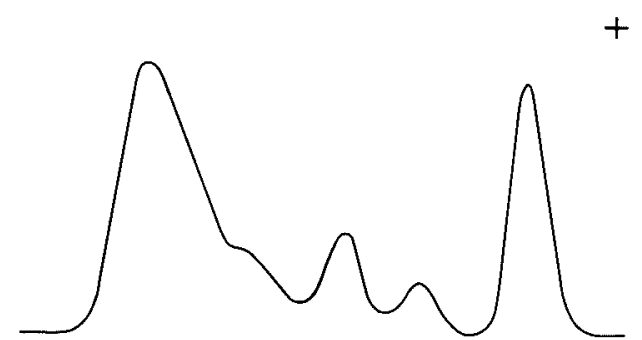

Fig. 2. Electrophoretic pattern on cellulose-acetate at the time of admission. Total protein $8.3 \mathrm{~g} / 100 \mathrm{ml}$. Albumin $20.7 \%, a_{1}$-globulin $4.1 \%, a_{2}$-globulin $11.4 \%, \beta$ globulin $9.8 \%, \gamma$-globulin $53.9 \%$.

for 3 months with no improvement.

His family history reveals no significant illness among the family. He has no history of exposure to asbestos.

Physical examination at the time of admission revealed an emaciated man who appeared pale. Temperature $38.5^{\circ} \mathrm{C}$. Pulse rate $110 / \mathrm{min}$. BP $130 / 180 \mathrm{~mm} \mathrm{Hg}$. Multiple small-finger-tip size lymph nodes were palpable in both cervical, axillar and inguinal areas. The lungs were clear. No heart murmurs were audible. The abdomen was slightly distended and shifting dullness was present. There was some tenderness over the epigastric and rt. hypochondriac area. The liver, spleen and kidneys were not palpable. No pedal edema was detected.

The laboratory examinations at the time of admission are shown in Table 1. Hypochromic anemia was present with decrease of serum iron. The liver functions were not extremely deranged. ESR was increased to $152 \mathrm{~mm}$ in one hour. The test for rheumatoid factors was negative, while ASLO titer was increased to 833 . LE cells were not demonstrated and antinuclear factors were not present. Direct Coombs' test was positive, but subsequent studies employing an elution technique disclosed that this was due to non-specific binding of $\gamma$-globulin to the surface of red cells. Sternal bone marrow aspiration revealed that the marrow contained 174,000 nucleated cells per cubic millimeter with 3 per cent plasma cells, no abnormal cell being detected. Subsequent bone marrow studies, however, showed gradual increase in plasma cell percentage as shown in Fig. 1. The level of serum total protein was $8.3 \mathrm{~g} / 100 \mathrm{ml}$ with $53.9 \%$ of $\gamma$-globulin, its electrophoretic pattern on cellulose-acetate membrane being shown in Fig. 2. This marked elevation of $\gamma$-globulin was persistent and gradually increased, reaching $68.9 \%$ of total serum protein which became 12.4 g/100 ml. Fig. 3 shows the results of immunoelectrophoretic analysis, determining ultimately the polyclonal nature of the hypergammaglobulinemia suggested by the broad pattern of $\gamma$-globulin increase in cellulose acetate membrane. The results of quantitation of various immunoglobulins are shown in Table 1. Fig. 4 demonstrates the pattern of ultracentrifugal analysis of the patient's serum, revealing that the increased protein consisted mainly of $7 \mathrm{~S}$ globulin.

The course after admission is shown in Fig. 5. Since the various antibiotics 


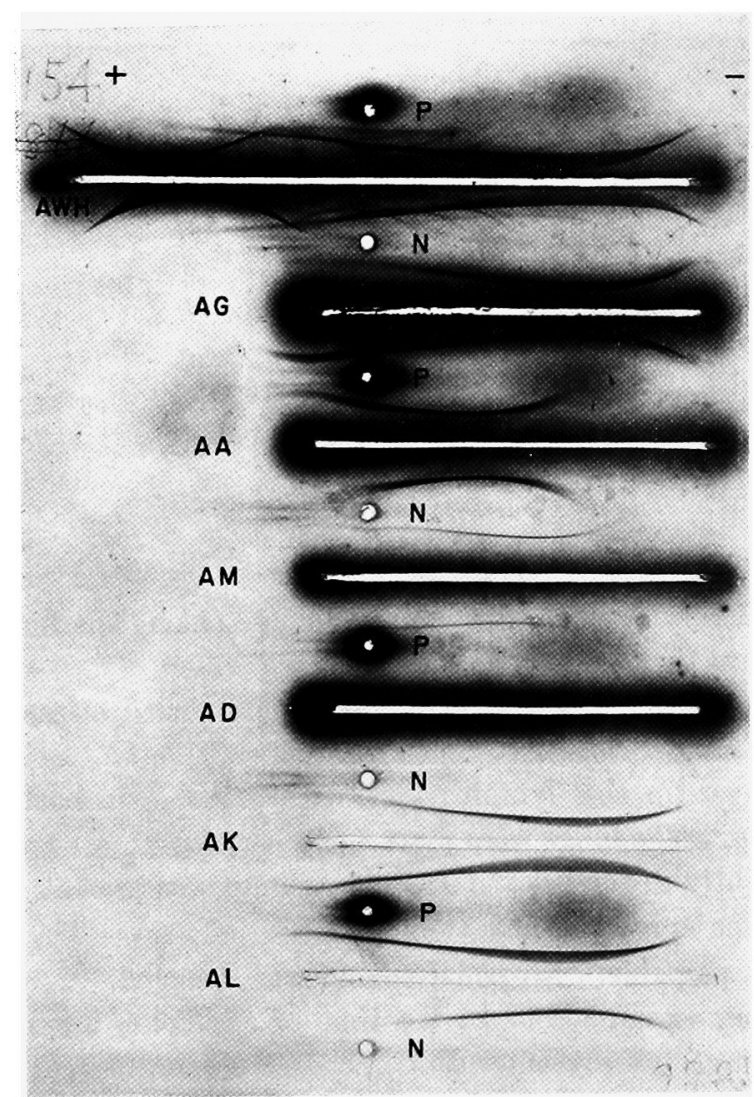

Fig. 3. The results of immunoelectrophoresis. $\mathbf{P}$, patient's serum; $\mathrm{N}$, normal serum; AWH, anti-whole human serum; AG, anti-IgG serum; AA, anti-IgA serum; AM, anti-IgM serum; $A D$, Anti-IgD serum; $A K$, anti- $\kappa$ light chain serum; $A L$, anti- $\lambda$ light chain serum.

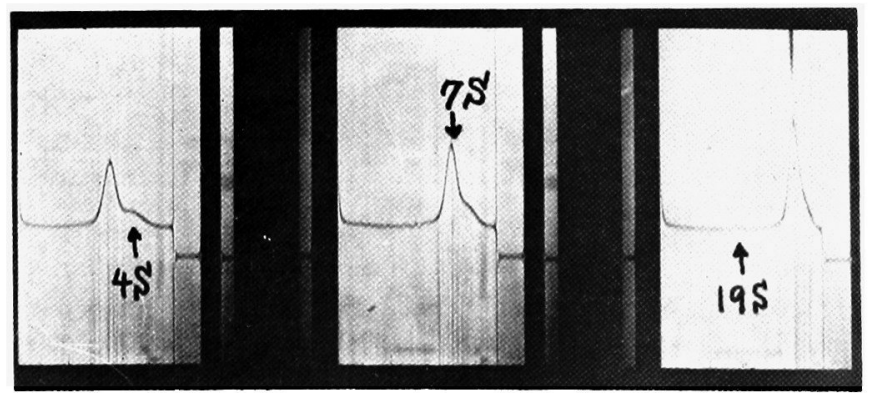

Fig. 4. Ultracentrifugal analysis of patient's serum. Photos were taken every 15 minutes. $60,000 \mathrm{rpm}$.

probable diagnosis of tuberculous peritonitis he received anti-tuberculous agents failed to suppress the temperature elevation, adrenal corticosteroid and indomethacine were employed with some response to fever. There was no improvement, 


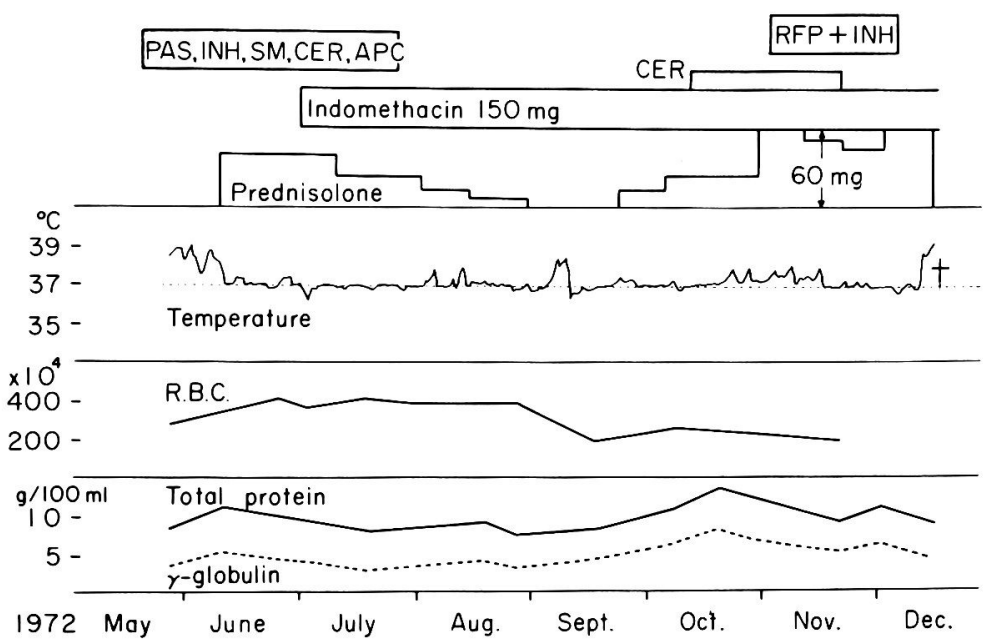

Fig. 5. Course after admission to Tohoku University Hospital. PAS, $p$-aminosalicylic acid; CER, Cephaloridine; INH, Isoniazid; APC, Ampicillin; SM, Streptomycin; RFP, Rifampicin.

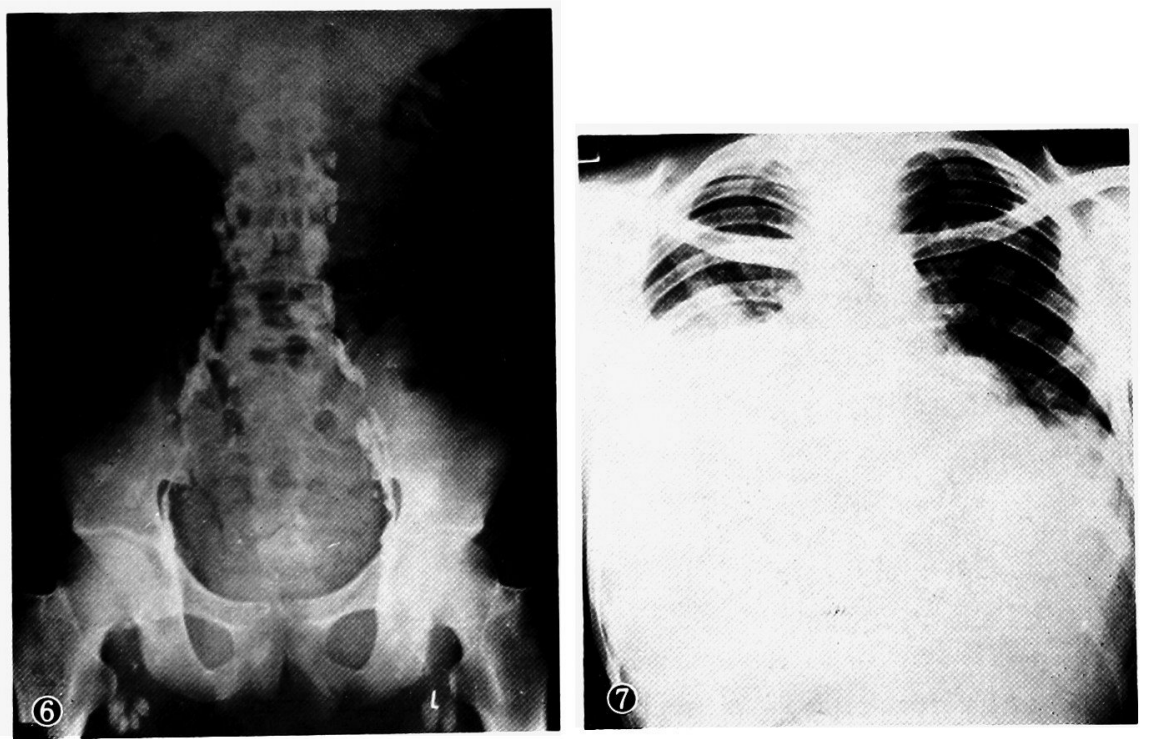

Fig. 6. Lymphangiographic picture of retroperitoneal lymph nodes.

Fig. 7. Chest $\mathrm{X}$-ray demonstrating pleural effusion in the right side.

however, in ESR acceleration and in hypergammaglobulinemia. As hyperglycemia became excessive, reaching to glucose level of $314 \mathrm{mg} / 100 \mathrm{ml}$, the adrenal corticosteroid was decreased and then stopped. Meanwhile cervical lymph node biopsy, laparoscopy, and examination of ascitic fluid were performed with no significant information. The lymphangiographic picture is shown in Fig. 6, revealing some granular pattern of the retroperitoneal lymph nodes. His condition deteriorated 


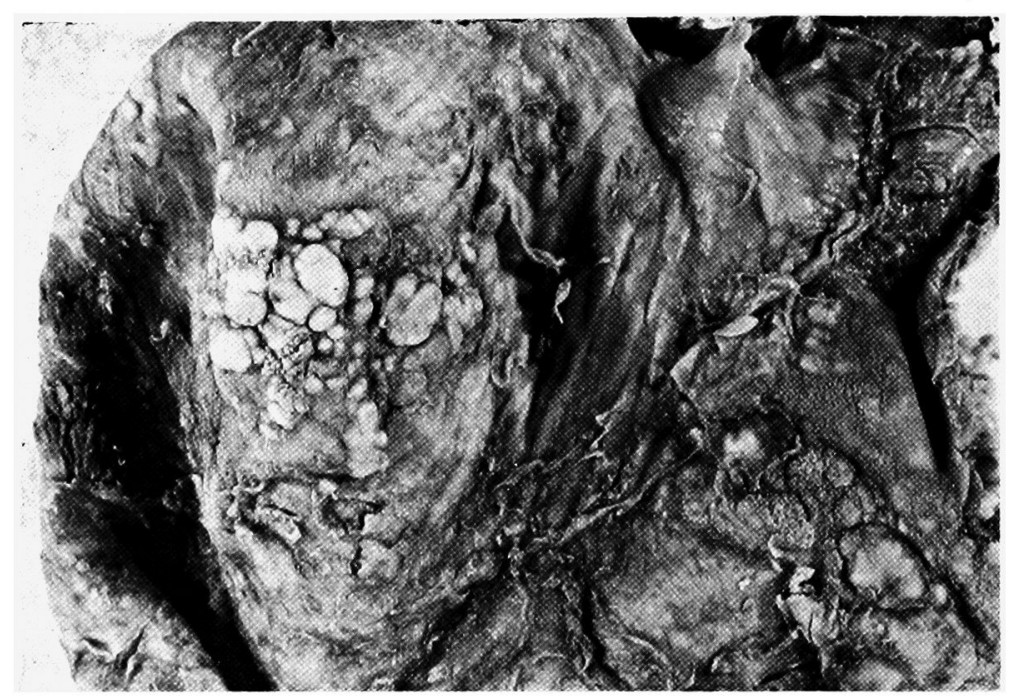

Fig. 8. Tumors of mesothelioma under the right diaphragm.

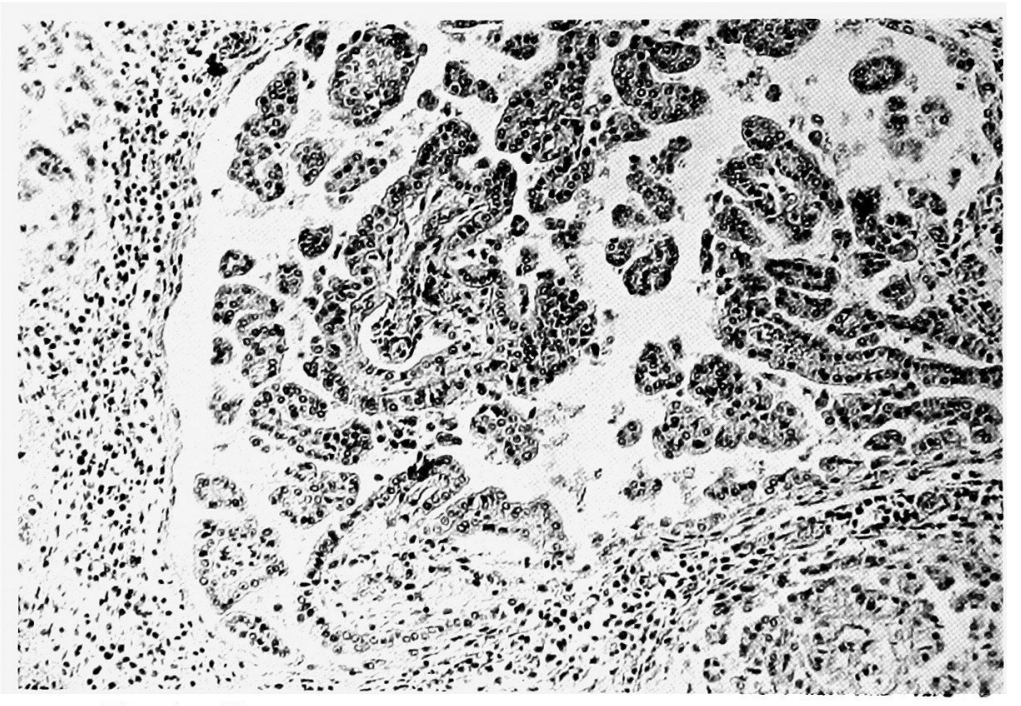

Fig. 9. Histological view of the section of mesothelioma.

gradually with increase of abdominal pain and ascites. In October, 1972 pleural effusion also was noted as demonstrated roentgenologically in Fig. 7. The analysis of the pleural fluid revealed the increase of protein, but no abnormal cell was detected. The culture of the fluid gave no growth of bacteria. In spite of the readministration of adrenal corticosteroid and antituberculous agents, no recovery was seen. Towards the end of his course increase of BUN and serum creatinine was observed, jaundice, hepatomegaly and dyspnea becoming prominent. On December 13, 1972 he expired. 


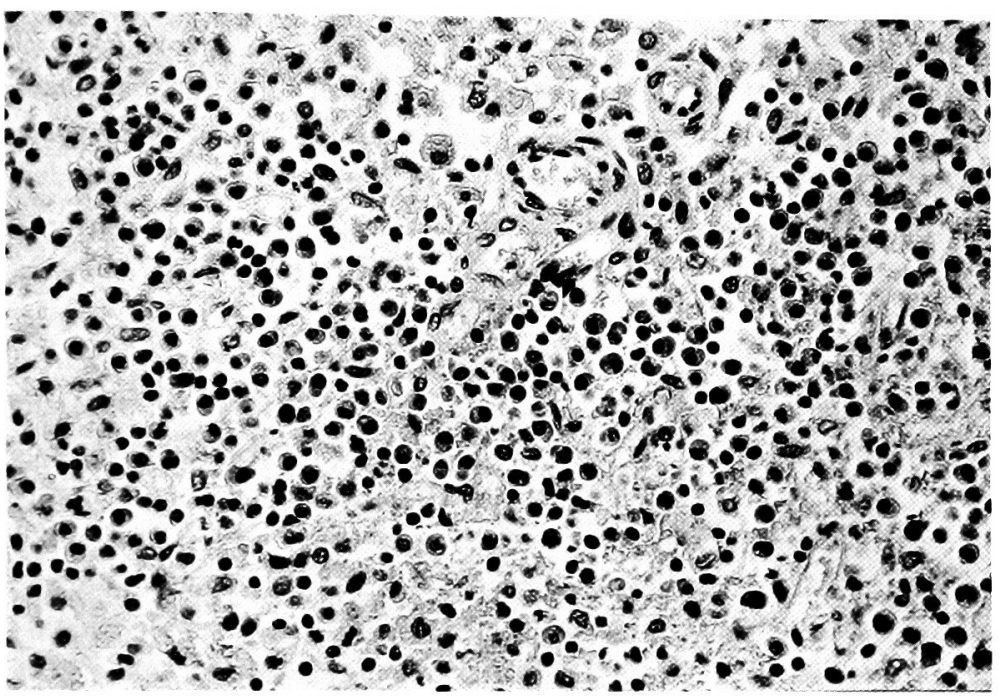

Fig. 10. Histological picture of a distant lymph node.

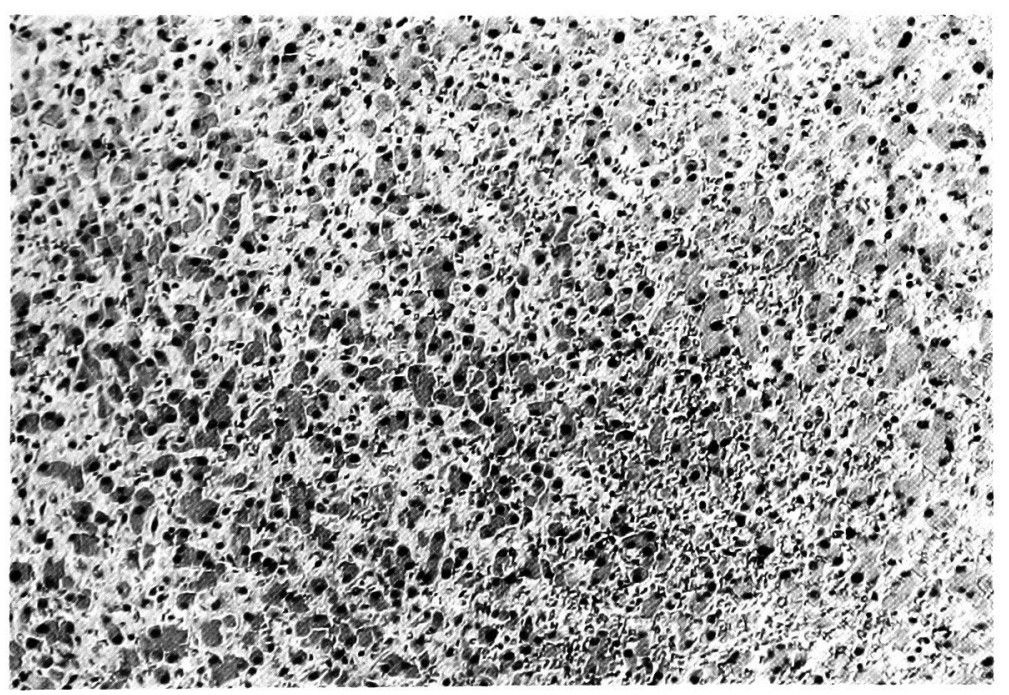

Fig. 11. Histological picture of the liver at the time of autopsy.

Upon autopsy the most remarkable feature was the presence of numerous confluent coarsely granular tumors in the right subphrenic space as is shown in Fig. 8. Histologically the mesothelioma cells showed papillary proliferation, covering in one layer the surface of connective tissue which contained abundant capillaries, as shown in Fig. 9, and was classified as mesothelioma of epithelial type. The tumor cells were cuboidal and showed no atypia, but metastases to the neighboring lymph nodes were definitely recognized. Metastases to distant lymph nodes and other 
organs were not demonstrated. Generalized distant lymph nodes, however, showed plasma cell proliferation as shown in Fig. 10.

Other prominent pathological findings were fibrinous pericarditis and enlarged liver with dark red tone. Histological picture of the liver is shown in Fig. 11 which demonstrated the destruction of basic liver structure. This was regarded as toxic hepatitis which appeared shortly before death.

\section{Discussion}

Malignant mesothelial tumors are relatively rare and present difficult diagnostic problems (Smith et al. 1968; Roberts and Irvine 1970). It was reported that confidence in the diagnosis of diffuse mesothelioma during an autopsy rested on the ability to exclude other tumors (McCaughey 1965). In one report, however, 30 cases of mesothelioma were studied histopathologically (Churg et al. 1965). The association of the mesothelioma occurrence to asbestos exposure has been suggested (Hourihane 1965; Vigliani et al. 1965; McDonald et al. 1970), and it is reported that the elevated level of acid mucopolysaccharide in serous effusion may be useful for the diagnosis of mesothelioma (Thompson et al. 1969).

Although no characteristic clinical pattern has been summarized, since reviews on mesothelioma seem to have been mainly on histopathology (Churg et al. 1965; McCaughey 1965) it may be regarded that gradual increase of abdonimal discomfort, ascites and emaciation are seen in peritoneal mesothelioma (Smith et al. 1968; Roberts and Irvine 1970), and pleural effusion and dyspnea occur in pleural mesothelioma (Persaud et al. 1970; September and Villet 1972). Differentiation from tuberculous peritonitis, collagn diseases and other malignant diseases may be extremely difficult as observed in the present case, unless mesothelioma be suspected.

The most prominent feature in the present case was the persistent and increasing hyperimmunoglobulinemia which took a chronic course. Although liver failure appeared terminally, we regard that this was due to administration of various drugs. Most case histories concerning mesotheliomas reported so far lacked in the descriptions of the detailed serum protein analysis, but we could accumulate 3 additional cases of mesothelioma with hypergammaglobulinemia from the world literature. Baran et al. (1972) reported a case of hyperglobulinemia associated with pleural mesothelioma and stated that it was not certain whether this hyperglobulinemia was related to mesothelioma or not. September and Villet (1970) also reported a case of monoclonal gammopathy associated with malignant mesothelioma and mentioned that the bone marrow of this patient showed diffuse plasma cell infiltration. However, since the immunoelectrophoretic pattern was not shown in this case, we wonder if this hypergammaglobulinemia was really monoclonal instead of polyclonal. Furthermore, as early as in 1954, Jallut (1954) reported a case of pleural mesothelioma associated with multiple myeloma. Although it may occasionally be difficult to differentiate between multiple myeloma and reactive plasmacytosis, it would not be denied that his case resembled our case. Our case, in addition to the 3 cases mentioned above may suggest that mesothelioma cell infiltration can cause 
the proliferation of plasma cells in the lymphoreticular system and lead to excessive production of immunoglobulins. Although this phenomenon may be seen in other malignancies (Fenoglio et al. 1973), the peculiar character of mesothelioma cell invasion might be more prone to cause plasma cell proliferation than other malignant cells such as carcinoma cells. However, what the precise mechanism of this plasma cell proliferation is, and whether it is related to some antigenic stimulus or mere mechanical stimulation await further studies.

\section{Acknowledgment}

We are indebted to Prof. N. Sasano and Dr. N. Tamahashi, Department of Pathology, Tohoku University School of Medicine, for performing the pathological studies.

\section{References}

1) Baran, E., Vacariu, O., Dobre, D. \& Dorescu, G. (1972) Polyglobulia and pleural mesothelioma. Rev. Med. Chir. Soc. Med. Nat. Iasi, 16, 763-766.

2) Barnett, L.J. \& MacDonald, N.S. (1970) Altered immunoglobulin metabolism in systemic lupus erythematosus and rheumatoid arthritis. J. clin. Invest., 49, 708715 .

3) Buchley, C.E. \& Dorsey, F.C. (1970) A comparison of serum immunoglobulin concentrations in sarcoidosis and tuberculosis. Ann. intern. Med., 72, 37-42.

4) Churg, J., Rosen, S.H. \& Moolten, S. (1965) Histological characteristics of mesothelioma associated with asbestos. Ann. N.Y. Acad. Sci., 132, 614-622.

5) Fahey, J.L. (1965) Antibodies and immunoglobulins. II. Normal development and changes in diseases. J. Amer. med. Ass., 194, 255-258.

6) Fenoglio, C., Ferenczy, A., Isobe, T. \& Osserman, E.F. (1973) Hepatoma associated with marked plasmacytosis and polyclonal hypergammaglobulinemia. Amer. J. Med., $55,111-115$.

7) Hourihane, D.O'B. (1965) A biopsy series of mesotheliomata, and attempts to identify asbestos within some of the tumors. Ann. N.Y. Acad. Sci, 132, 647-673.

8) Jallut, O. (1954) Reaction plasmacytaire ou myelome vrai dans un cas de mesotheliome pleural. Schweiz. med. Wschr., 84, 1110-11 2.

9) MoCaughey, W.F.E. (1965) Criteria for diagnosis of diffuse mesothelial tumors. Ann. N.Y. Acad. Sci, 132, 603-613.

10) MeDonald, A.D., Harper, A., El Attar, O.A. \& MeDonald, J.C. (1970) Epidemiology of primary malignant mesothelial tumors in Canada. Cancer, 26, 914-919.

11) Onodera, S. (1966) Quantitative determination of serum immunoglobulins in various diseases. Tohoku J. exp. Med., 89, 279-292.

12) Persaud, V., Bateson, E.M. \& Bankay, C.D. (1970) Pleural mesothelioma associated with massive hepatic calcification and unusual metastases. Cancer, 26, 920-928.

13) Roberts, G.H. \& Irvine, R.W. (1970) Peritoneal mesothelioma. A report of 4 cases. Brit. J. Surg., 57, 645-650.

14) September, B.A. \& Villet, W.T. (1972) Monoclonal gammopathy associated with malignant mesothelioma: case report. South Afri. med. J., 46, 545-549.

15) Smith, P.G., Higgins, P. McR. \& Park, W.D. (1968) Peritoneal mesothelioma presenting surgically. Brit. J. Surg., 55, 681-685.

16) Thompson, M.E., Bromberg, P.A. \& Amenta, J.S. (1969) Acid mucopolysaccharide determination. A useful adjunct for the diagnosis of malignant mesothelioma with effusion. Amer. J. clin. Path., 52, 335-339.

17) Vigliani, E.C., Mottura, G. \& Maranzana, P. (1965) Association of pulmonary tumors with asbestosis in Piedmont and Lombardy. Ann. N.Y. Acad. Sci., 132, 558-576. 